\title{
Size structure, maturity size, growth and condition index of stone crayfish (Austropotamobius torrentium) in North-West Croatia
}

\author{
I. Maguire ${ }^{(1)}$, G. Klobučar ${ }^{(1)}$ \\ Received January 15, 2011 \\ Revised March 3, 2011 \\ Accepted March 18, 2011
}

Key-words: stone crayfish, growth, maturity size, condition index, Croatia

\section{ABSTRACT}

Austropotamobius torrentium (Schrank, 1803), the smallest species of freshwater crayfish from the family Astacidae, is considered a vulnerable species, protected by international laws. Since it has never been economically important, it has not been frequently studied. Therefore, the results presented in this paper are a contribution to the knowledge on stone crayfish's population size structure, size at maturity, growth, and condition index throughout the year, as a possible tool for evaluating protection and restocking measures of this threatened species. The research included three stone crayfish populations with 1492 specimens in the "Medvednica" Nature Park, north-west Croatia, during a period of 18 months. In all the populations studied, crayfish of a total length between 5 and $8 \mathrm{~cm}$ prevailed. Activity of different size classes had a seasonal pattern that could be connected to different crayfish activities throughout the year. Appearance of sexual maturity within the populations coincides with the crayfish total length between 5 and $6 \mathrm{~cm}$, after which allometric growth of males' claws was recorded. On average males gain $0.42-0.72 \mathrm{~cm}$ and $2.65-4.30 \mathrm{~g}$ per moult, while females gain $0.44-0.70 \mathrm{~cm}$ and $2.04-3.83 \mathrm{~g}$. Crayfish condition varied throughout the year with, in general, both juvenile and adult males having higher condition indices than juvenile and adult females in all three populations. In addition, adult crayfish were in significantly better condition in the autumn, whereas juveniles had higher condition indices in the summer.

\section{RÉSUMÉ}

Structure en taille, taille à la maturité, croissance et indice de condition de l'écrevisse des torrents (Austropotamobius torrentium) dans le nord-ouest de la Croatie

Mots-clés:
écrevisse
des torrents,
croissance,
taille à la
maturité,
indice de
condition,
Croatie

Mots-clés :

Austropotamobius torrentium (Schrank, 1803), la plus petite des espèces d'écrevisses d'eau douce de la famille des Astacidae, est classée comme espèce vulnérable protégée par les lois internationales. Comme elle n'a jamais eu d'importance économique, elle n'a pas été souvent étudiée. Pour cette raison, les résultats présentés dans cet article sont une contribution à la connaissance de la structure en taille de populations d'écrevisses des torrents, de la taille à maturité, de la croissance et de l'indice de condition au cours d'une année, comme moyen possible d'évaluation des mesures de protection et de réintroduction de cette espèce menacée. Cette recherche porte sur trois populations d'écrevisses des torrents avec 1492 individus échantillonnés dans le parc naturel « Medvednica », au nord-ouest

(1) University of Zagreb, Faculty of Science, Department of Zoology, Rooseveltov trg 6, 10000 Zagreb, Croatia, imaguire@zg.biol.pmf.hr 
de la Croatie, pendant une période de 18 mois. Dans toutes les populations étudiées, la plupart des écrevisses mesurent entre 5 et $8 \mathrm{~cm}$. L'activité des différentes classes de taille présente un schéma saisonnier qui peut être relié aux différents traits de vie pendant une année. La maturité sexuelle dans ces populations est observée pour une longueur totale entre 5 et $6 \mathrm{~cm}$, à partir de laquelle la croissance allométrique des pléopodes mâles est observée. En moyenne, les mâles gagnent $0,42-0,72 \mathrm{~cm}$ et $2,65-4,30 \mathrm{~g}$ par mue, et les femelles $0,44-0,70 \mathrm{~cm}$ et 2,04-3,83 g. L'indice de condition varie dans l'année avec, en général, les juvéniles et adultes mâles ayant un indice de condition supérieur à celui des femelles juvéniles et adultes dans les trois populations. De plus, les écrevisses adultes présentent un meilleur indice de condition en automne, alors que les juvéniles ont un meilleur indice en été.

\section{INTRODUCTION}

The importance of crayfish in the food webs of freshwater habitats has been recognised for a long time; thus, they are regarded as a flagship species for comprehensive water protection (Füreder and Reynolds, 2003; Füreder et al., 2003).

The stone crayfish (Austropotamobius torrentium) is one of four native European freshwater crayfish species inhabiting Croatian freshwater habitats. It can be found at higher altitudes in streams and rivers belonging to the Black Sea and the Adriatic Sea drainages (Maguire and Gottstein-Matočec, 2004; Maguire et al., 2006). Also, in Europe A. torrentium mainly inhabits headwater sections of small, fast-running brooks (Kappus et al., 1999; Streissl and Hödl, 2002), although lake populations have also been recorded (Vorburger and Ribi, 1999; Renz and Breithaupt, 2000). The territory of $A$. torrentium in Europe extends from Germany and the Czech Republic in the north, to Luxembourg in the west, Greece in the south and Bulgaria and Turkey in the east (Holdich et al., 2006, 2009).

Currently, stone crayfish populations are disappearing due to anthropogenic influence (Füreder et al., 2006). Their natural habitats are usually isolated and frequently separated by habitat destruction and barriers, hence often when a local population disappears, no natural recolonisation occurs (Bohl, 1997). Besides environmental stress, they are also endangered by the presence and expansion of invasive non-indigenous crayfish species (NICS) that displace them from their habitats (Söderbäck, 1995; Huber and Schubart, 2005). Therefore, the stone crayfish is considered as an endangered species and is listed in Appendix III of the Bern Convention, in Annexes II and V of the Habitat Directive on the conservation of natural habitats and of wild fauna and flora, and in the IUCN Red List of threatened species (Füreder et al., 2010). In Croatia it is also protected by Croatian legislation (Narodne novine, 1999, 2008).

The relatively small size of stone crayfish makes them unsuitable for intensive commercial exploitation (Laurent, 1988), which is probably one of the reasons why they have not been more frequently studied (Bohl, 1987; Laurent, 1988; Troschel et al., 1995; Renz and Breithaupt, 2000; Streissl and Hödl, 2002; Holdich et al., 2006).

Endangered species conservation and management measures include protection of existing populations and finding alternative habitats where (re)introduction could be accomplished. Such programmes, amongst other things, require a good knowledge of the population structure and dynamics (Gherardi et al., 1996; Belchier et al., 1998; Streissl and Hödl, 2002; Peay, 2009), all the more so because these analyses are expected by the Water Framework Directive 2000/60 ECC in action plans for the preservation of water and its resources (Scalici et al., 2008).

As information on the population dynamics of $A$. torrentium is scarce in the literature (Laurent, 1988; Streissl and Hödl, 2002; Huber and Schubart, 2005), the present research, on stone crayfish populations in north-west Croatia, was carried out with the aim of extending 
Table I

Definition of size classes according to total length (TL).

Tableau I

Définition des classes de taille selon la longueur totale $(T L)$.

\begin{tabular}{|l|c|}
\hline$T L(\mathrm{~cm})$ & Size class \\
\hline $0-3.99$ & 1 \\
\hline $4-4.99$ & 2 \\
\hline $5-5.99$ & 3 \\
\hline $6-6.99$ & 4 \\
\hline $7-7.99$ & 5 \\
\hline $8-8.99$ & 6 \\
\hline $9-9.99$ & 7 \\
\hline$>10$ & 8 \\
\hline
\end{tabular}

the knowledge on the populations' size structure, size at the onset of sexual maturity and appearance of allometric growth. Another purpose was to study crayfish growth (length and weight per moult increment and growth speed) within the studied populations, as well as to identify the condition of the stone crayfish in their natural environment.

\section{MATERIAL AND METHODS}

Populations of $A$. torrentium were studied during an 18-month period (from October 1998 to April 2000) in three streams: Sarni, Kraljevec and Mrzlak (GPS coordinates 5572469 and 5089956, 5574081 and 5080141, and 5572728 and 5079956, respectively; the coordinate system HR_GK_5) situated on the slopes of the Medvednica Mountain within the borders of Medvednica Nature Park. All three streams have shallow banks and flow through beechchestnut forests. The riverbed of the streams consists of stones, rocks and pebbles, offering plenty of shelters for crayfish. The physico-chemical characteristics of the studied streams were similar (Maguire et al., 2002). The sites were surveyed twice a month and 25 baited traps made of PVC bottles (of a cylindrical shape) with funnel entrances (made from plastic net, mesh size $=2 \mathrm{~mm}$ ) at both ends (Maguire et al., 2002) were exposed at approximately $10-\mathrm{m}$ intervals along the banks, under stones or tree roots, and left in the stream overnight.

All of the trapped crayfish were sexed, and checked for moulting state (soft-shell/hard-shell) and mating state (existence of glair glands, presence of pleopodal eggs). Weight $(W)$ (using a Pesola balance) and total length (TL) (using a Vernier calliper), from the tip of the rostrum to the end of the telson, as well as right claw length $(C H L)$, carapace length $(C L)$ and carapace width $(\mathrm{CW})$ were measured. In the case of a missing or regenerating right claw, the left claw was measured. Before releasing crayfish back into the water all of the individuals were marked by piercing a hole in the telson and/or uropodes according to Guan (1997). The mark-recapture method enables determination of length and weight increments per moult. For estimation of the populations' size structure, size classes were arbitrarily set (Table I).

Seasons were defined as: spring - March, April, May; summer - June, July, August; autumn September, October, November; winter - December, January, February.

Two condition indices (adopted from Streissl and Hödl, 2002) were calculated; Fulton's Condition Factor $\left(F C F=W / T L^{3}\right)$; and the Crayfish Constant $(C C=W / T L+C L+C W)$. When comparing obtained indices values between populations, only similar-sized specimens of the same sex should be evaluated, because it is known that in $A$. torrentium these indices are size- and sex-dependent (Streissl and Hödl, 2002). All of the crayfish with missing appendages were omitted from the analyses.

All the analyses (descriptive statistics, T-test, ANOVA with post-hoc tests, Kruskal-Wallis ANOVA with post-hoc test, Mann-Whitney $U$ test) were performed using the statistical programs Microsoft Excel 2007 and Statistica 8 for Windows (StatSoft, Inc.). The considered level of significance was set at 0.05 . 
I. Maguire and G. Klobučar: Knowl. Managt. Aquatic Ecosyst. (2011) 401, 12

\section{Table II}

Number of captured and recaptured males $(m)$ and females (f) per population.

Tableau II

Nombre de captures et recaptures des mâles (m) et femelles (f) par population.

\begin{tabular}{|l|c|c|c|c|c|c|}
\hline Population & \multicolumn{2}{|c|}{ Sarni } & \multicolumn{2}{|c|}{ Kraljevec } & \multicolumn{2}{|c|}{ Mrzlak } \\
\hline Sex & $\mathrm{m}$ & $\mathrm{f}$ & $\mathrm{m}$ & $\mathrm{f}$ & $\mathrm{m}$ & $\mathrm{f}$ \\
\hline Capture & 112 & 102 & 348 & 306 & 322 & 292 \\
\hline Recapture & 13 & 7 & 79 & 56 & 105 & 61 \\
\hline
\end{tabular}

\section{RESULTS AND DISCUSSION}

Field research is a common source of information for the study of population dynamics, and could be useful for planning in situ monitoring activities, in addition to having a role in (re)introduction programmes during restocking projects (Grandjean et al., 2000; Scalici et al., 2008). It is advantageous, compared with laboratory studies, because populations are studied in natural conditions (Johnson, 2004). Application of mark-recapture methods provides data needed for estimation of animals' growth parameters, especially for species such as crayfish that cannot be aged directly (Brewis and Bowler, 1982; Hamr, 1996; Guan and Wiles, 1999; Streissl and Hödl, 2002; Jones and Coulson, 2006; Scalici et al., 2008).

During the research period a total of 1492 crayfish were caught (Table II).

\section{> SIZE STRUCTURE}

In the studied populations the majority of captured crayfish had a total length between 5 and $8 \mathrm{~cm}$ (size classes 3, 4 and 5), with a lesser proportion of smaller and bigger crayfish (size classes 1 and 2, and 6, 7 and 8) (Figure 1). The results obtained probably underestimated smaller size classes, because it is known that when traps are used as catching gear, smaller size classes are trapped, but it seems that mainly adult crayfish prevail in the traps (Brown and Brewis, 1979; Gherardi et al., 1996; Rabeni et al., 1997; Grandjean et al., 2000; Dorn et al., 2005). So even with a large sample size, length-frequency distributions obtained from trap catches do not necessarily describe the real population structure. Therefore, capturing crayfish with traps should be combined with hand-catching and/or electrofishing (Gherardi et al., 1996; Lewis and Horton, 1996). Additionally, it should be pointed out that according to Bohl (1989, cf. Huber and Schubart, 2005) a non-selective hand catch of 20 individuals that fit into at least six size classes (5-mm TL intervals) represents a stable population status. Even though we used traps as catching gear and 10-mm TL interval size classes, in the period of high activity (September), during one sampling session in all three populations we obtained specimens that fit into at least six size classes. Therefore, we may conclude that all three populations could be characterised as stable.

To gain information about the different size classes' activity throughout the seasons, histograms were built separately for males and females (Figures 2-4).

As expected, all size classes showed a minimal winter activity in all populations. No activity for any size class, either in males or in females, was observed in the Sarni population (Figure 2). In the Kraljevec population some activity of medium-sized females and males (size classes 3 , 4, 5 and 6) was recorded (Figure 3), while minimal activity of all size classes, both males and females, existed in the Mrzlak population (Figure 4). Similar winter activity was observed for white-clawed crayfish (Gherardi et al., 1996; Grandjean et al., 2000). In the spring some slight activity of the smallest size classes (size classes 1 and 2) was observed (Figures 2-4). In all three populations medium-sized classes' activity was observed, with more pronounced activity of males in the Sarni and Kraljevec populations, and equal numbers of active males and females in the Mrzlak population (Figures 2-4). The observed differences are possibly a consequence of a difference in activity between the sexes (Grandjean et al., 2000). In the summer, higher activity of smaller size classes, compared with previous seasons, was observed for all 


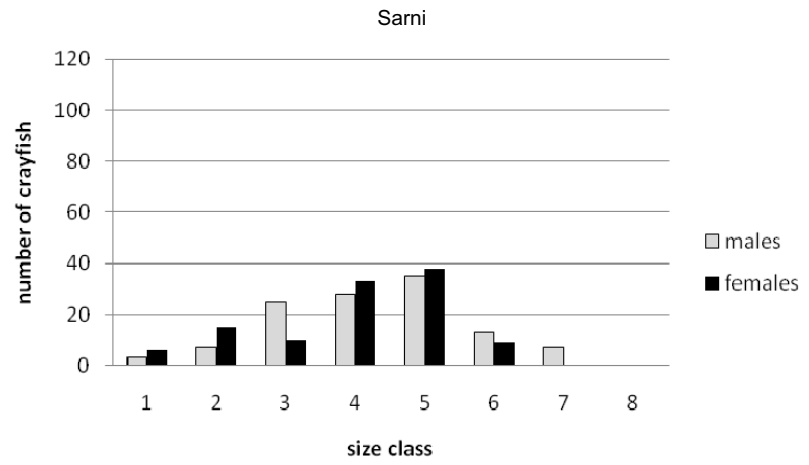

(a)

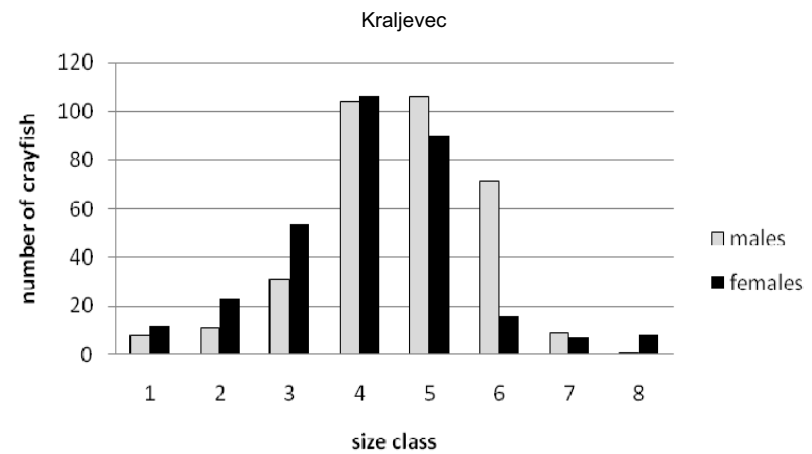

(b)

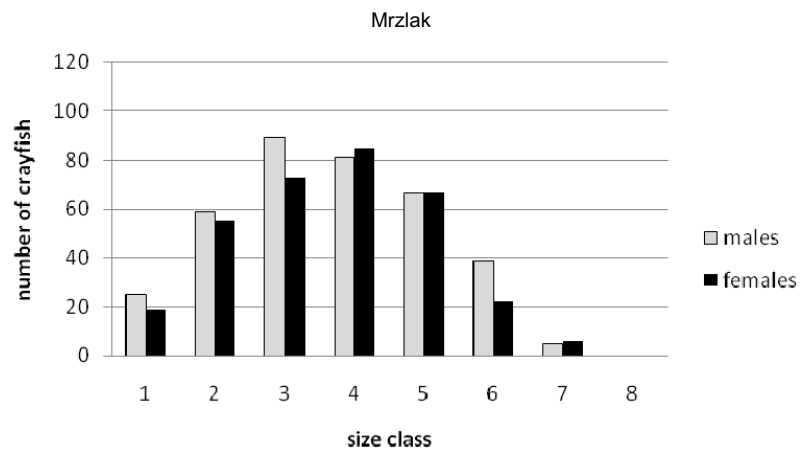

(c)

\section{Figure 1}

Size class frequency histograms of crayfish captured during the survey in the Sarni (a), Kraljevec (b) and Mrzlak (c) populations.

\section{Figure 1}

Histogramme de fréquence de classes de taille des écrevisses capturées pendant le suivi des populations de Sarni (a), Kraljevec (b) et Mrzlak (c).

three populations (Figures 2-4). Compared with the small size classes, activity of medium size classes was apparent. In the Sarni population females of size classes 4 and 5 were more active than males (Figure 2), while in the Kraljevec population it was vice versa (Figure 3), and in the Mrzlak population males' and females' activity was similar (Figure 4). The observed higher activity in summer compared with spring is due to the fact that summer is a period of food abundance. Also, adult females that hatched juveniles became more active in the summer, as well as males that moulted earlier in the season (Maguire et al., 2002). In the autumn, activity of small-sized males and females increased (Figures 2-4). In the Sarni population autumn was the season when the medium-sized males had a peak in their activity, and females 

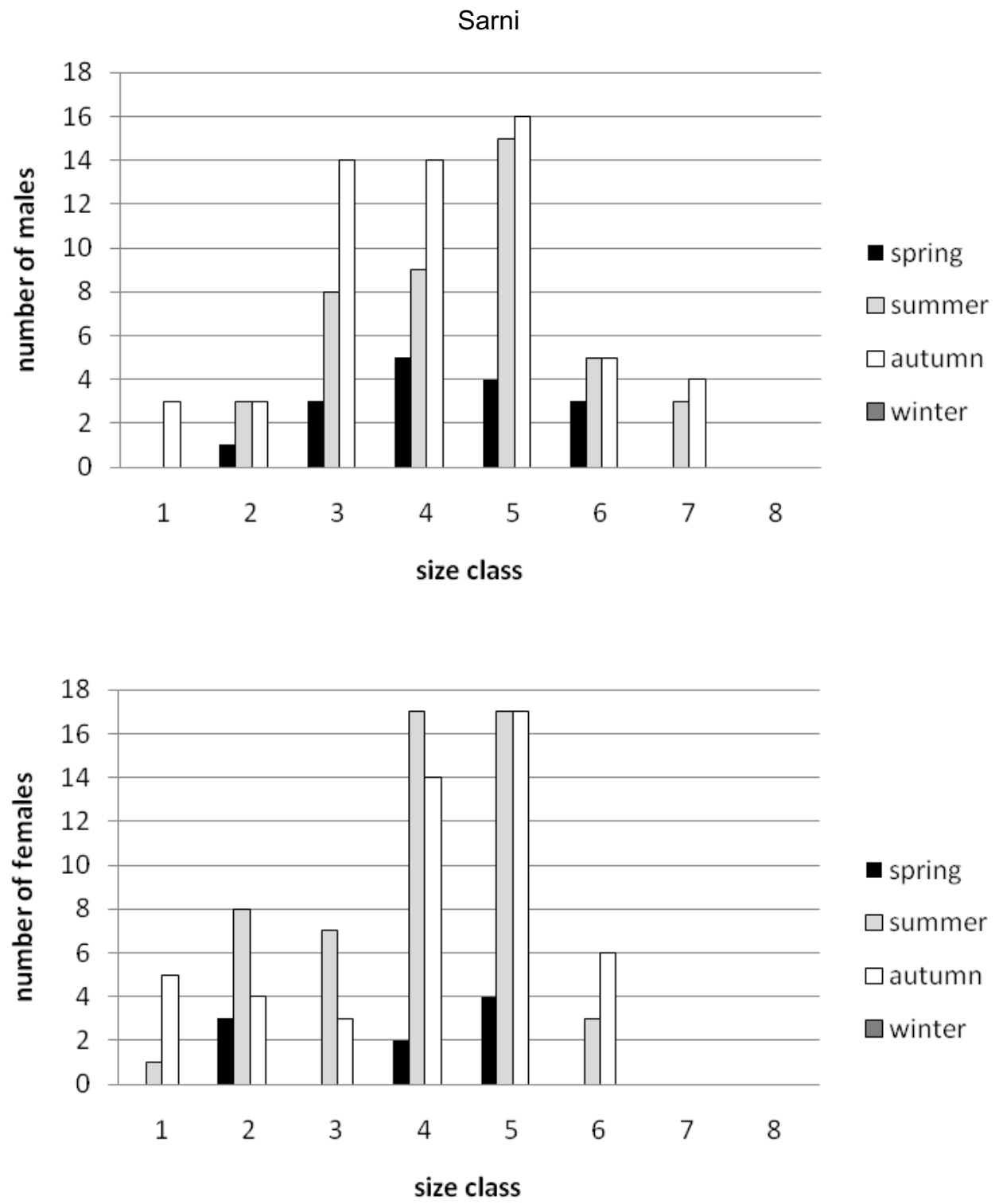

Figure 2

Histogram of activity of different size classes for males and females throughout different seasons in the Sarni population.

Figure 2

Histogramme d'activité des différentes classes de taille des mâles et des femelles au cours des saisons dans la population Sarni.

showed a similar trend, but not so pronounced (Figure 2). In the Kraljevec population the situation was reversed: medium-sized females had a peak of their activity in the autumn, while males' activity was high, but not higher than in the summer (Figure 3). In the Mrzlak population medium-sized males and females were equally active, but their activity was less pronounced than in the summer (Figure 4). Autumn is a season when stone crayfish mating is recorded in Croatian freshwater habitats (Maguire et al., 2002): therefore, high activity of medium-sized crayfish was to be expected (Grandjean et al., 2000). The highest activity of the smallest size classes coincided with autumn, possibly due to the fact that young-of-the-year crayfish, that entered populations in early summer, became more active and were intensely feeding as preparation for winter starvation (Parkyn et al., 2002). 

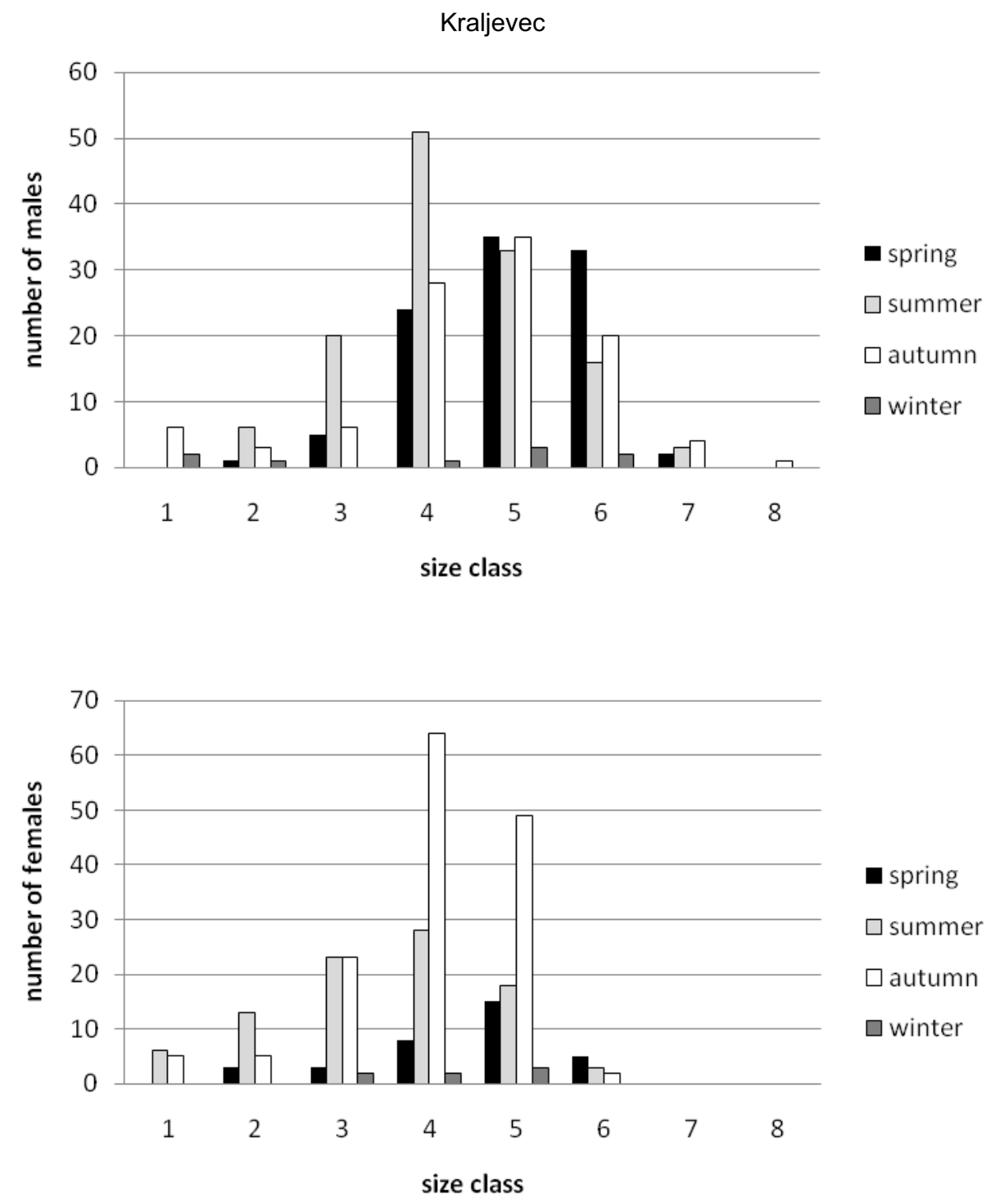

\section{Figure 3}

Histogram of activity of different size classes for males and females throughout different seasons in the Kraljevec population.

\section{Figure 3}

Histogramme d'activité des différentes classes de taille des mâles et des femelles au cours des saisons dans la population Kraljevec.

\section{> SIZE AT MATURITY}

To determine crayfish size at maturity within the studied populations, keeping in mind that males' claws grow allometrically after attaining sexual maturity (Lowery, 1988; Grandjean et al., 1997; Streissl and Hödl, 2002), we calculated crayfish total length against the ratio of their claw's length to total length separately for males and females (Figures 5a-5c).

In all three populations claws grew similarly in males and females up to their total length between 5 and $6 \mathrm{~cm}$, after which the size ratio of claw length to total length started to increase rapidly in males from Kraljevec and Mrzlak (Figures 5b-5c). The same trend, less pronounced, was observed in the Sarni population (Figure 5a). The results obtained could be associated with appearance of sexual maturity (Grandjean et al., 1997; Streissl and Hödl, 2002). Therefore, $6 \mathrm{~cm} T L$ was taken as a size to separate juvenile (pre-mature) and adult (mature) crayfish 
Mrzlak
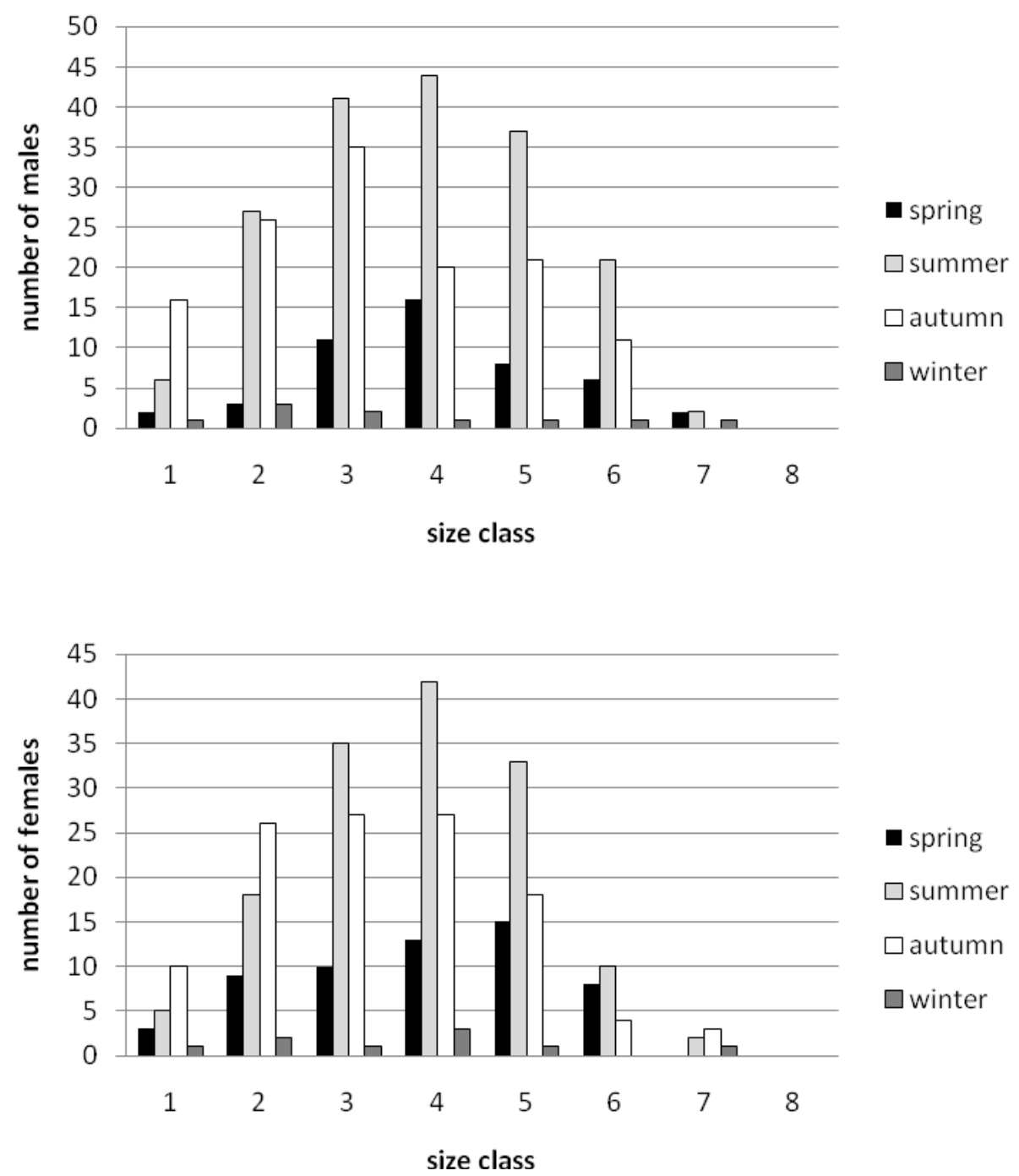

Figure 4

Histogram of activity of different size classes for males and females throughout different seasons in the Mrzlak population.

Figure 4

Histogramme d'activité des différentes classes de taille des mâles et des femelles au cours des saisons dans la population Mrzlak.

in further analyses. Affirmation for the established size was also found in the presence of glair glands, as a reliable sign of sexual maturity (Abrahamsson and Goldman, 1970; Lewis and Horton, 1996; Grandjean et al., 2000) in females longer than $6 \mathrm{~cm}$ TL (Maguire et al., 2002). According to the literature data, the size at maturity of stone crayfish is said to be between 3.5 and $5.0 \mathrm{~cm}$ TL (Holdich et al., 2006). Streissl and Hödl (2002) in their research on the Austrian stone crayfish populations found that females reach sexual maturity at a $T L$ between 5.9 and $6.5 \mathrm{~cm}$, while Huber and Schubart (2005) determined that females in Bavaria become mature at a $T L$ greater than $4.5 \mathrm{~cm}$. That indicates that in the Croatian populations sexual maturity is attained at a bigger size than is recorded by some authors (Huber and Schubart, 2005; Holdich et al., 2006). It is known that mature animals are larger in favourable conditions than those from habitats with high densities, reduced food availability and poor water quality 


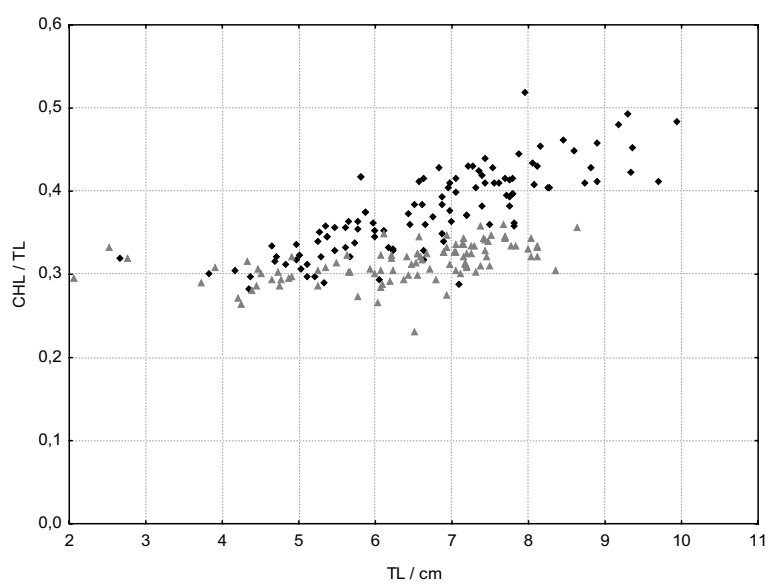

(a)

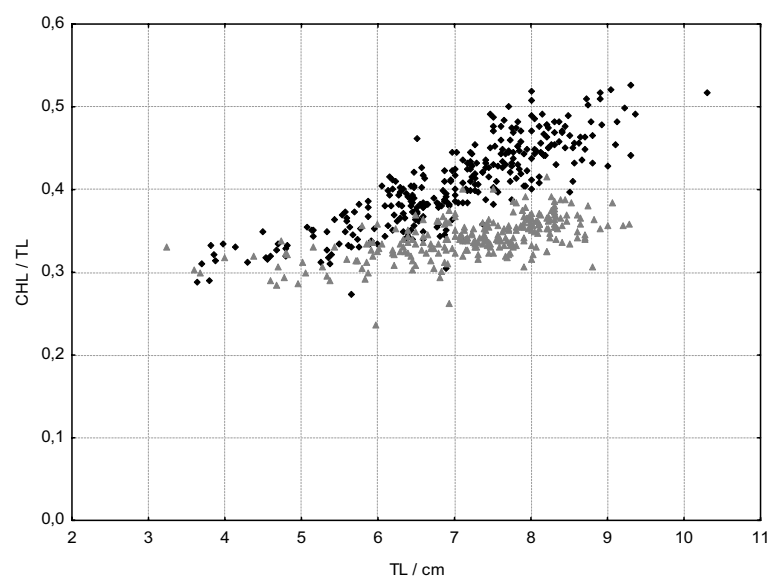

(b)

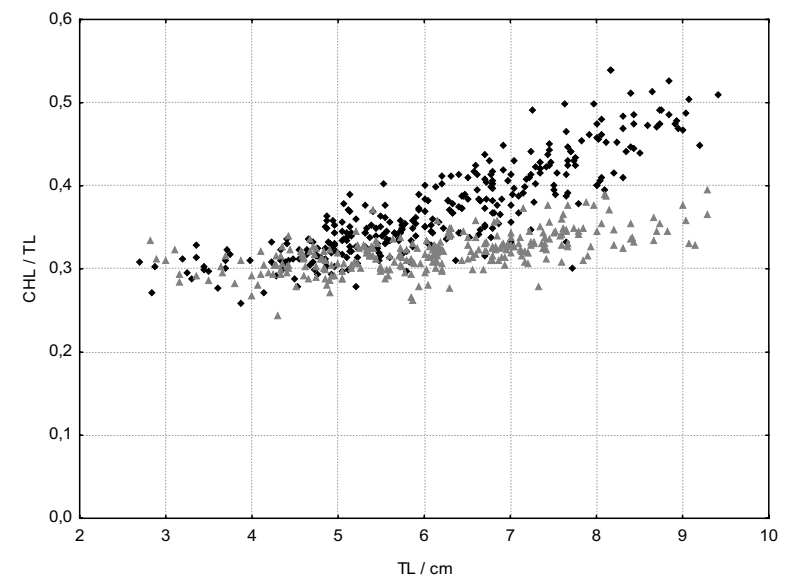

(c)

\section{Figure 5}

The relationship between total length $(T L)$ and the ratio of claw length to total length (CHL/TL) for males (black diamonds) and females (grey triangles) in the Sarni (a), Kraljevec (b) and Mrzlak populations (c).

\section{Figure 5}

Relation entre la longueur totale $(T L)$ et le rapport de la longueur du pléopode à la longueur totale $(C H L / T L)$ pour les mâles (losanges noirs) et les femelles (triangles gris) dans les populations Sarni (a), Kraljevec (b) et Mrzlak (c). 


\section{Table III}

Weight (W gain, $\mathrm{g}$ ) and length (TL gain, $\mathrm{cm}$ ) increment, number of weeks between capture and recapture (No. weeks), ratio of $g$ (W speed) or cm (TL speed) and weeks between the 1st and 2nd catch for males $(M)$ and females (F) from the studied populations (the number of analysed individuals is given in brackets). Mean values are given with minimal and maximal values in brackets.

\section{Tableau III}

Incrément en poids (g) et en longueur (cm), nombre de semaines entre capture et recapture, accroissement relatif en poids et longueur par semaine des populations étudiées (le nombre d'individus figure entre parenthèses). Les moyennes sont données avec les valeurs extrêmes entre parenthèses.

\begin{tabular}{|l|c|c|c|c|c|c|}
\hline Population & Sex $(\mathrm{N})$ & W gain $(\mathrm{g})$ & $T L$ gain $(\mathrm{cm})$ & No. weeks & W speed $\left(\mathrm{g} \cdot\right.$ week $\left.^{-1}\right)$ & $T L$ speed $\left(\mathrm{cm}^{-w^{-1}}\right)$ \\
\hline \multirow{4}{*}{ Sarni } & $\mathrm{M}$ & 4.30 & 0.72 & 6.74 & 0.78 & 0.12 \\
& $(5)$ & $(2.00-7.50)$ & $(0.60-0.81)$ & $(4.0-11.4)$ & $(0.26-1.88)$ & $(0.06-0.20)$ \\
\cline { 2 - 7 } & $\mathrm{F}$ & 3.83 & 0.70 & 7.53 & 0.55 & 0.10 \\
& $(3)$ & $(3.00-5.50)$ & $(0.48-1.03)$ & $(6.3-10.0)$ & $(0.30-0.87)$ & $(0.06-0.16)$ \\
\hline \multirow{5}{*}{ Kraljeve } & $\mathrm{M}$ & 2.65 & 0.47 & 14.46 & 0.21 & 0.05 \\
& $(13)$ & $(0.00-6.00)$ & $(0.22-0.73)$ & $(2.3-24.2)$ & $(0.00-0.43)$ & $(0.01-0.19)$ \\
\cline { 2 - 7 } & $\mathrm{F}$ & 2.04 & 0.45 & 17.08 & 0.13 & 0.03 \\
& $(14)$ & $(0.00-5.50)$ & $(0.10-1.18)$ & $(6.4-26.1)$ & $(0.00-0.44)$ & $(0.01-0.09)$ \\
\hline \multirow{5}{*}{ Mrzlak } & $\mathrm{M}$ & 3.94 & 0.42 & 12.89 & 0.36 & 0.05 \\
& $(18)$ & $(0.00-7.00)$ & $(0.11-0.74)$ & $(2.1-19.3)$ & $(0.00-0.95)$ & $(0.01-0.31)$ \\
\cline { 2 - 7 } & $\mathrm{F}$ & 2.20 & 0.44 & 14.28 & 0.20 & 0.03 \\
& $(10)$ & $(0.00-6.00)$ & $(0.25-0.70)$ & $(6.0-27.4)$ & $(0.00-0.67)$ & $(0.02-0.05)$ \\
\hline
\end{tabular}

(Huner and Romaire, 1978; Nyström and Granéli, 1996), so we may conclude that habitat conditions in the studied streams are favourable for stone crayfish populations.

\section{> ABSOLUTE GROWTH AND GROWTH SPEED}

The weight and total length measurements of recaptured crayfish (Table II) were used to calculate weight and length increment as well as growth speed. Although advantageous, markrecapture methods are also demanding (Thorsteinsson, 2002) because during application many details should be considered. Precise morphometrical measurements should be taken at the first catch and at the recapture, and animals must be marked carefully so they are not injured (Scalici et al., 2008). Enough time has to pass between capture and recapture so crayfish can moult once, but not too much, because crayfish could moult more than once (Guan and Wiles, 1999; Ulmestrand and Eggert, 2001). In addition, juvenile crayfish are not reliable in this type of study because it is known that marking them could reduce their growth rate (Guan, 1997). Juvenile crayfish also moult more frequently, which could lead to increased loss of marks, and it is hard to tell if they have moulted once or more times between two field sessions (Nowicki et al., 2008).

Taking all that into consideration, in this work a relatively low number of adult males and females could be included in the growth increment and growth speed analyses (Table III). A similar number was used in the research on Nephrops norvegicus (Linnaeus, 1758) (Ulmestrand and Eggert, 2001), Austropotamobius pallipes (Lereboullet, 1858) (Gherardi et al., 1996) and Scyllarides latus (Latreille, 1802) (Bianchini et al., 2001).

Moulting within the Kraljevec and Sarni stone crayfish populations was observed from the beginning of June until the beginning of October, while in the Mrzlak population moulting was recorded from mid-May until the beginning of October. In all three streams during the moulting period water temperature was above $9^{\circ} \mathrm{C}$, which is lower than that recorded by Streissl and Hödl (2002) in their research on stone crayfish in Austria.

The recorded weight and length gains as well as estimated growth speed (ratio of $\mathrm{cm}$ or $\mathrm{g}$ and weeks between the 1st and 2nd catch) are presented in Table III. The results of our research showed that the average absolute length increment in $A$. torrentium males was similar to the recorded values for $A$. pallipes (Gherardi et al., 1996). Estimated average growth speed 


\section{Table IV}

Results of post-hoc comparisons of mean ranks between populations. (a) $\mathrm{p}$ Values for weight gain (W gain) - above diagonal and length gain ( $T L$ gain) - under diagonal. (b) p Values for weight speed (W speed) - above diagonal and length speed (TL speed) - under diagonal.

\section{Tableau IV}

Résultat des comparaisons post-hoc des rangs entre population. Les valeurs de $p$ sont indiquées : gain de poids versus gain en longueur, vitesse d'augmentation de poids versus en longueur.

(a)

(b)

\begin{tabular}{|l|c|c|c|}
\hline W Wain gain & Sarni & Kraljevec & Mrzlak \\
\hline Sarni & & 0.101 & 0.892 \\
\hline Kraljevec & 0.007 & & 0.314 \\
\hline Mrzlak & 0.003 & 1.00 & \\
\hline
\end{tabular}

\begin{tabular}{|l|c|c|c|}
\hline TL speed & Sarni & Kraljevec & Mrzlak \\
\hline Sarni & & 0.0004 & 0.030 \\
\hline Kraljevec & 0.0002 & & 0.185 \\
\hline Mrzlak & 0.001 & 1.00 & \\
\hline
\end{tabular}

obtained for stone crayfish (Table III) was lower compared with growth speed of some other crayfish species, e.g. red swamp crayfish, Procambarus clarkii (Girard, 1852) (Anastácio and Marques, 1995). However, this was to be expected, knowing that the stone crayfish grows more slowly and can live for more than 10 years (Holdich et al., 2006), while red swamp crayfish is a fast-growing species of short life span (rarely more than 12-18 months in nature) (Holdich et al., 2006).

Comparisons of females' and males' weight and length gains within the studied populations, using the Mann-Whitney $U$ test, showed that there were no significant differences between the sexes either in weight or length increment (Sarni population: $p=1.00$ and $p=0.55$; Kraljevec population: $p=0.37$ and $p=0.34$; Mrzlak population: $p=0.06$ and $p=0.81$ for weight and length increment, respectively). It is known that, in general, male crayfish grow faster than females because their length increment per moult is larger (Skurdal and Taugbøl, 1994; Grandjean et al., 1997; Streissl and Hödl, 2002), but there are exceptions; no differences in growth increment between the sexes were found for Astacopsis gouldi Clark, 1936 (Hamr, 1996) or for Procambarus alleni (Faxon, 1884) (Acosta and Perry, 2000). No recorded significant difference in the weight increment between the sexes could be due to the fact that during growth the increase in males' claws is offset by an increase in females' abdomens (Lewis and Horton, 1996).

The results of the Mann-Whitney $U$ test showed that there were no significant differences in the growth speed between males and females within populations (Sarni population: $p=1.00$ and $p=0.55$; Kraljevec population: $p=0.07$ and $p=0.17$; Mrzlak population: $p=0.08$ and $p=0.68$ for weight and length speed, respectively). Similar results were found in the research on P. alleni (Acosta and Perry, 2000).

Since there were no significant differences between the sexes within populations, either in the length and weight increment or in the growth speed, data for both sexes were pooled together for further analyses.

The results of the Kruskal-Wallis ANOVA showed that there were no significant differences in the weight gain between populations, but significant differences were recorded for length gain, and weight and length speed. Post-hoc comparisons of mean ranks showed that significant differences existed between the population from the Sarni Stream and the other two populations (Table IV), indicating that crayfish from the Sarni Stream gained more length per moult and that they grew faster.

However, the results of the Kruskal-Wallis ANOVA showed that significant differences in the time-span between the 1 st and the 2 nd catch existed between the Sarni population and 
the other two populations (post-hoc comparisons of mean ranks: $p=0.012$ and $p<0.001$ for Mrzlak and Kraljevec, respectively). Actually, the time-span between the 1st and the 2nd catch for individuals from the Sarni Stream was much shorter (Table III) compared with the other two populations, which probably caused the apparently higher growth speed. The results obtained on the significantly higher length increment for crayfish from the Sarni population should also be regarded with caution because of the small number of individuals included in the analysis. It is known that growth is highly variable both within a species and between species due to a number of abiotic and biotic factors (Acosta and Perry, 2000). Different environmental factors, such as water temperature or calcium concentration in water, can influence crayfish growth (Jones, 1981; France, 1985; Lowery, 1988; Parkyn et al., 2002; Hammond et al., 2006). Nevertheless, crayfish growth is also influenced by the quality and availability of food, population density (Abrahamsson, 1966; Ackefors et al., 1992; Nyström and Granéli, 1996; Guan and Wiles, 1999; Parkyn et al., 2002; Barki et al., 2006) and genetic background (Fevolden and Hessen, 1989; Ackefors et al., 1995; Parkyn et al., 2002).

\section{$>$ CONDITION INDEX}

Crayfish condition varied throughout the year with, in general, males having significantly higher condition indices than females ( $t$-value $=6.63$, $d f=1031$ and $p<0.001 ; t$-value $=$ 14.09, df $=1031$ and $p<0.001$ for the $C C$ and $F C F$, respectively) (Table V, Figure 6), which is similar to the findings of Lindquist and Lahti (1983) and Streissl and Hödl (2002). The differences obtained are possibly caused by the bigger-sized claws in males, as proposed by Streissl and Hödl (2002).

It was found that in $A$. torrentium condition indices (CC and FCF) are correlated with crayfish size (Streissl and Hödl, 2002). Consequently, only similar-sized specimens of the same sex can be compared when using FCF and the CC (Streissl and Hödl, 2002). Therefore, in further analyses juvenile $(<6 \mathrm{~cm} \mathrm{TL})$ and adult $(>6 \mathrm{~cm} \mathrm{TL}$ ) crayfish, as well as the two sexes, were treated separately.

ANOVA (with the Bonferroni post-hoc test) was applied to compare condition indices between adult and juvenile crayfish, within populations, separately for males and females, irrespective of season. No significant differences were obtained, either for the CC or for $F C F$, for males and females from the Sarni population (Table VI). In the Kraljevec population the FCF index was significantly higher in adult males (Table $\mathrm{VI}$ ), while both the CC and FCF indices were significantly higher in juvenile females (Table VI). In the Mrzlak population there were no significant differences in condition indices between adult and juvenile females (Table VI), while again, the FCF index was significantly higher in adult males (Table VI). From the results obtained it seems that the FCF index is slightly more sensitive when used for detection of differences between different groups (juveniles - adults). In addition, our results showed that in some populations adult males showed higher condition indices compared with juvenile ones, which could be connected to their bigger size (Streissl and Hödl, 2002). Females from the Kraljevec population showed opposite results; generally, juvenile females had significantly higher condition indices than adult ones, which could be a consequence of the fact that energy in mature females is used for reproduction activities (Grandjean et al., 1997).

ANOVA (with the Bonferroni post-hoc test) was applied to compare indices within populations between juvenile and adult crayfish per season (for the winter season comparisons were not made because of the small number of trapped crayfish), separately for males and females. Some trends were observed, with several differences between indices and populations (Table VII). Generally, it seems that in the spring and autumn adult crayfish had higher condition indices than juveniles, while in the summer it was the reverse, with juvenile crayfish having higher condition indices compared with adults. This could be explained by the fact that crayfish condition is connected to moulting and reproductive activities, so adult crayfish consume some of the bodily reserves built up in spring for summer moulting and in preparation for mating, while during the mating season adult, reproductively active crayfish, are at the peak of their condition (Anastácio and Marques, 1995; Streissl and Hödl, 2002). 


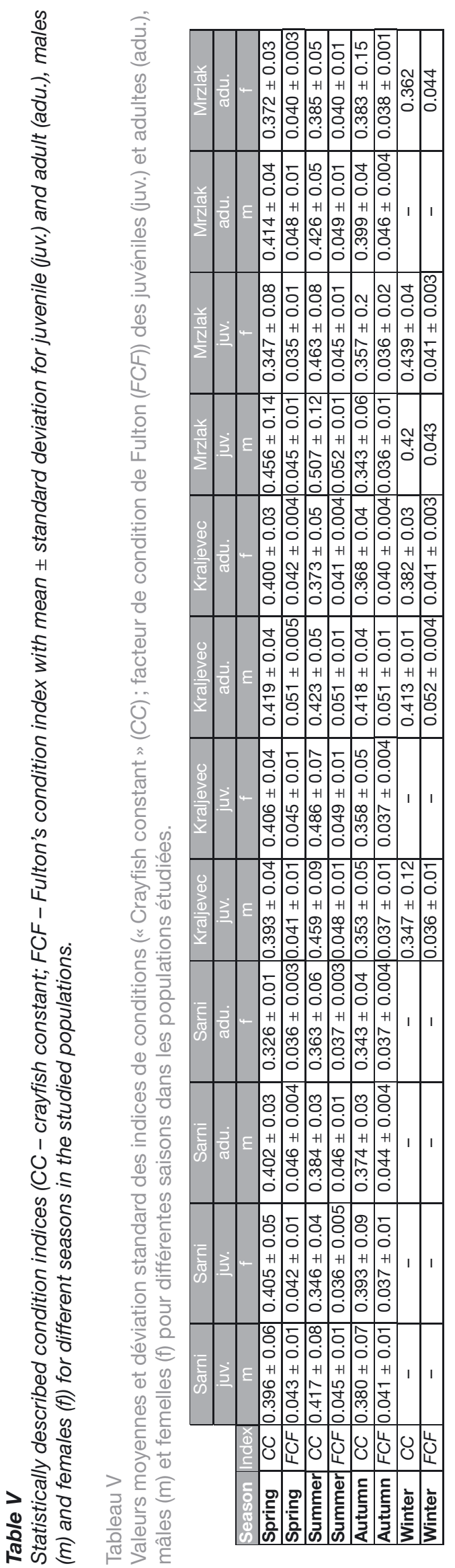




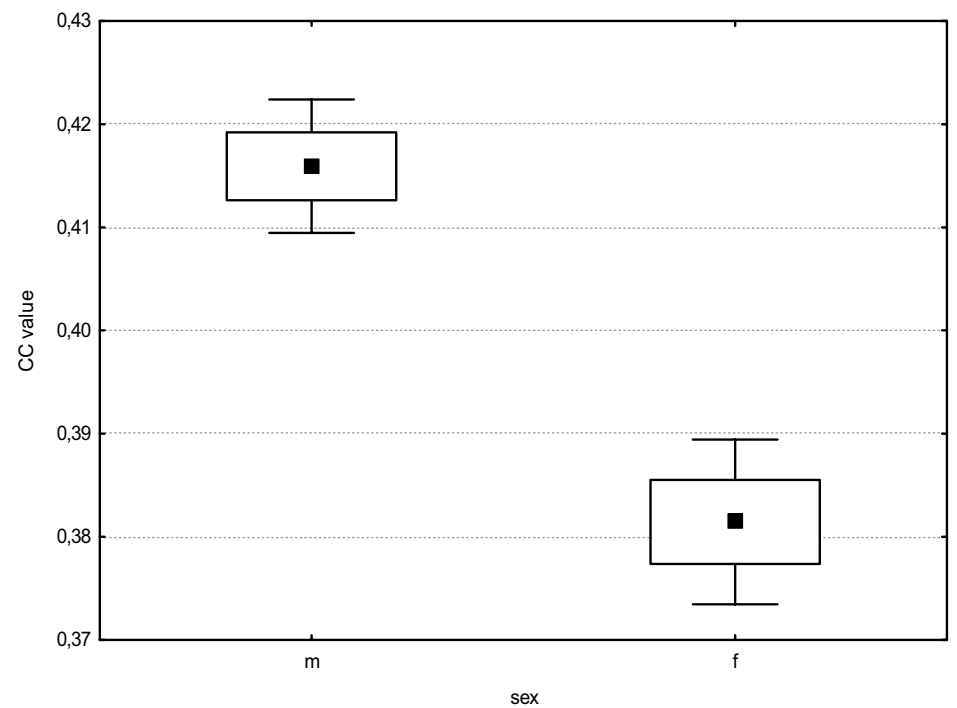

(a)

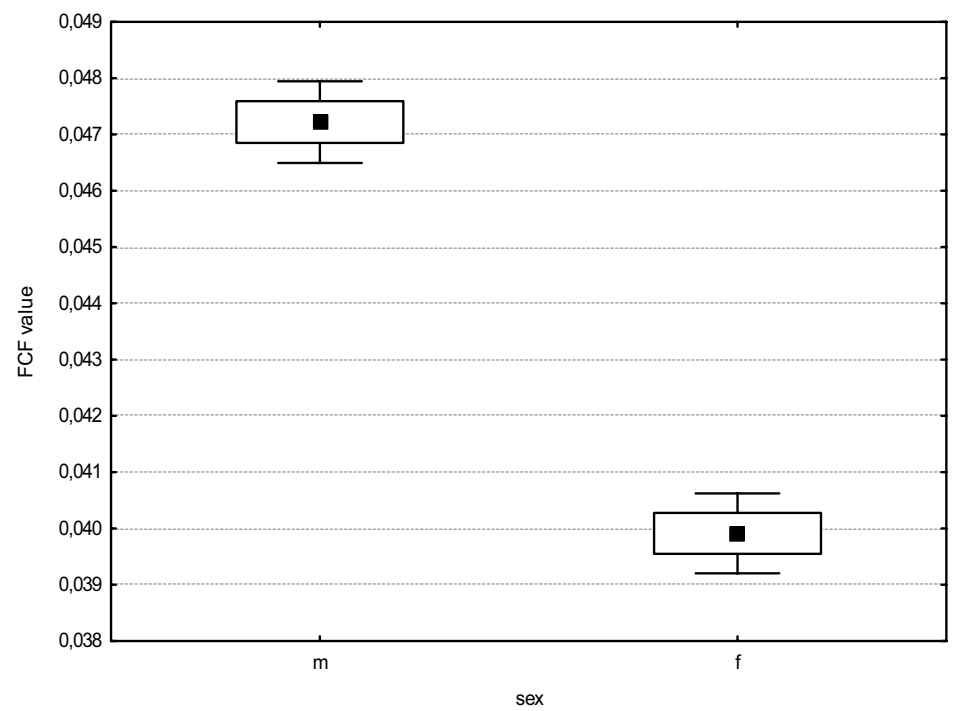

(b)

Figure 6

Condition indices of males and females irrespective of season, population and crayfish size. (a) Crayfish constant (CC). (b) Fulton's condition factor (FCF). Data are presented as mean (squares), standard error of mean (box) and 95\% confidence interval (whiskers).

\section{Figure 6}

Indice de condition des mâles et des femelles indépendamment des saisons, populations et taille des écrevisses. (a) «Crayfish constant» $(C C)$. (b) Facteur de condition de Fulton (FCF). Les carrés représentent les moyennes, la boîte l'erreur-standard de la moyenne et les moustaches l'intervalle de confiance à $95 \%$.

Finally, we compared condition indices among the different populations for adult males and females separately, irrespective of season. The results of the ANOVA showed that significant differences for both indices existed among populations. The Fisher LSD post-hoc test revealed that the value of the $C C$ index significantly differed between males from the Sarni population and the other two populations, while the values of the FCF index were significantly different among males in all three populations (Table VIIla). Identical results were obtained 


\section{Table VI}

Results of the Bonferroni post-hoc test for condition indices (CC and FCF) comparisons between juvenile and adult males $(m)$ and females $(f)$ in the studied populations. $p$ Values are given.

\section{Tableau VI}

Résultats du test post-hoc de Bonferroni de comparaison des indices de condition (CC et FCF). entre juvéniles et adultes mâles ( $m$ ) et femelles ( $f$ ) dans les populations étudiées. Les valeurs de $p$ sont indiquées.

\begin{tabular}{|l|c|c|c|c|c|c|}
\hline \multirow{2}{*}{ Index } & \multicolumn{2}{|c|}{ Sarni } & \multicolumn{2}{|c|}{ Kraljevec } & \multicolumn{2}{|c|}{ Mrzlak } \\
\cline { 2 - 7 } & $\mathrm{m}$ & $\mathrm{f}$ & $\mathrm{m}$ & $\mathrm{f}$ & $\mathrm{m}$ & $\mathrm{f}$ \\
\hline $\boldsymbol{C C}$ & 0.27 & 0.42 & 0.20 & $<0.001$ & 0.58 & 0.32 \\
\hline FCF & 0.72 & 0.56 & $<0.001$ & $<0.001$ & $<0.001$ & 0.97 \\
\hline
\end{tabular}

\section{Table VII}

Comparison of indices (CC - crayfish constant; FCF - Fulton's condition index) within populations between juvenile (juv.) and adult (adu.) crayfish per season, separately for males ( $m$ ) and females ( $f$ ). The sign + indicates a significantly higher value of the given index in favour of the juvenile or adult crayfish groups; fields without a sign indicate that there was no significant difference recorded in the given index between the juvenile and adult crayfish groups.

\section{Tableau VII}

Comparaisons des indices CC et FCF dans les populations entre juvéniles (juv.) et adultes (adu.) d'écrevisses par saison, séparément pour les mâles (m) et les femelles (f). Le signe + indique une valeur significativement plus grande; l'absence de signe indique qu'il n'y a pas de différence significative.

\begin{tabular}{|c|c|c|c|c|c|c|c|c|c|c|c|c|c|}
\hline & Sarn & Sarn & Sarn & Sarn & Kraljevec & Kraljevec & Kraljevec & Kraljeved & Mrzlak & Mrzlak & Mrzlak & Mrzlak \\
\hline & & juv. & adu. & juv. & adu. & juv. & adu. & juv. & adu. & juv. & adu. & juv. & adu. \\
\hline Season & Index & $m$ & $m$ & $f$ & $f$ & $m$ & $\mathrm{~m}$ & f & $f$ & $m$ & $m$ & $f$ & f \\
\hline Spring & CC & & & & & & & & & & & & \\
\hline Spring & $F C F$ & & & & & & + & & & & & & \\
\hline Summer & $C C$ & & & & & + & & + & & + & & + & \\
\hline Summer & $F C F$ & & & & & & & + & & & & + & \\
\hline \begin{tabular}{|l|} 
Autumn \\
\end{tabular} & $C C$ & & & & & & + & & & & + & & \\
\hline \begin{tabular}{|l|} 
Autumn \\
\end{tabular} & $F C F$ & & & & & & + & & + & & + & & \\
\hline
\end{tabular}

for females (Table VIIlb). The results showed that crayfish from the Kraljevec population had overall the best condition all year round, followed by crayfish from the Mrzlak population, while the lowest condition values were held by crayfish from the Sarni population.

Research by Streissl and Hödl (2002) revealed the relationship between crayfish condition and habitat characteristics. Their study established that higher current heterogeneity and higher diversity of substrate composition positively influenced crayfish condition. The same was found in our research; when we considered the habitat characteristics of the streams studied during this research (Maguire et al., 2002) and compared them with the results obtained for condition indices, we could establish a connection between them. In the Kraljevec Stream crayfish were the least stressed, without any anthropogenic influence upon their habitat and with a variety of suitable shelters in which they could hide to avoid aggressive contacts and reduce locomotive activity in search for a shelter, which in return resulted in their higher condition (Vorburger and Ribi, 1999; Streissl and Hödl, 2002). The Mrzlak Stream is situated on the outskirts of the city of Zagreb, and thus exposed to stronger anthropogenic influence, which could have influenced the crayfish condition. Finally, crayfish were introduced into the Sarni Stream in the 1970s so it is possible that this stream does not represent an ideal habitat for the stone crayfish, which possibly resulted in their overall lower condition, which is similar to findings by Streissl and Hödl (2002). Therefore, we may say that in this research condition indices were proven to be a useful tool for evaluation of crayfish condition from different habitats, and it seems that they realistically reflect the habitat influence on the stone crayfish condition throughout the year, which is similar to the findings of Streissl and Hödl (2002).

As a general conclusion, we may say that all three populations could be characterised as stable, with the majority of crayfish being 5 to $8 \mathrm{~cm} \mathrm{TL}$. Activity of different size classes 


\section{Table VIII}

Results of post-hoc Fisher LSD test comparisons of condition indices (CC - crayfish constant - above diagonal and FCF - Fulton's condition factor - under diagonal) among the different populations for adult males (a) and females (b) separately. $p$ Values are given.

\section{Tableau VIII}

Résultat des comparaisons par test post-hoc LSD de Fisher entre les indices de condition CC et FCF entre les différentes populations séparément pour les mâles $(\mathrm{m})$ et les femelles (f). Les valeurs de $p$ sont indiquées.

(a)

(b)

\begin{tabular}{|l|c|c|c|}
\hline FCF CC & Sarni & Kraljevec & Mrzlak \\
\hline Sarni & & $<0.001$ & $<0.001$ \\
\hline Kraljevec & $<0.001$ & & 0.995 \\
\hline Mrzlak & $<0.001$ & 0.001 & \\
\hline
\end{tabular}

\begin{tabular}{|l|c|c|c|}
\hline FCF $C C$ & Sarni & Kraljevec & Mrzlak \\
\hline Sarni & & 0.042 & 0.009 \\
\hline Kraljevec & $<0.001$ & & 0.315 \\
\hline Mrzlak & 0.002 & 0.009 & \\
\hline
\end{tabular}

throughout the year is connected with their physiology and life cycle. Sexual maturity in the studied populations was established at $6 \mathrm{~cm}$ TL, after which size allometric growth of males' claws was recorded. There were no significant differences in the absolute growth increment and estimated growth speed between the sexes. According to the results obtained, stone crayfish gained on average between 2.04 and $4.30 \mathrm{~g}$, and 0.42 and $0.72 \mathrm{~cm}$ per moult. Crayfish condition varied throughout the year, with adults' condition being generally higher in the spring and autumn, and juveniles' condition being higher in the summer, which could be connected to differences in the year cycle between juvenile and adult crayfish. Furthermore, crayfish condition differed among the studied populations, most probably as a consequence of the observed differences in their habitats.

Conservation programmes include protection of the habitat and existing populations as well as crayfish reintroduction or restocking in adequate habitats (Souty-Grosset and Reynolds, 2009). In the latter case, apart from taking care with the genetics of the stocking material and suitability of targeted habitats (Souty-Grosset and Reynolds, 2009), some crayfish donor population characteristics, such as population abundance, population "age" structure, crayfish condition, etc., should be considered. Therefore, the results obtained are useful guidelines that could be used in monitoring and protection programmes of this endangered species. Specifically, the autumn is the season when monitoring activities should be undertaken because all stone crayfish size classes are then active. In addition, according to our results, the most abundant parts of populations are crayfish between 5 and $8 \mathrm{~cm} \mathrm{TL}$, so they should be potentially used as a donor group. Taking into consideration that adult crayfish condition is the highest in the autumn, it would be ideal to carry out restocking (reintroduction) activities in that season, similar to recommendations made by Souty-Grosset and Reynolds (2009).

\section{ACKNOWLEDGEMENTS}

The authors wish to thank the two anonymous referees for useful comments and suggestions that improved the manuscript. We also greatly appreciate Adam P. Maguire's and Rapti Siriwardane's help in improving the English. 


\section{REFERENCES}

Abrahamsson S.A., 1966. Dynamics of an isolated population of the crayfish Astacus astacus Linné. Oikos, 17, 96-107.

Abrahamsson S.A.A. and Goldman C.R., 1970. Distribution, density, and production of the crayfish Pacifastacus leniusculus (Dana) in Lake Tahoe, California-Navada. Oikos, 21, 83-91.

Ackefors H., Castell J.D., Boston L.D., Räty P. and Svensson M., 1992. Standard experimental diets for crustacean nutrition research. II. Growth and survival of juvenile crayfish Astacus astacus (Linné) fed diets containing various amounts of protein, carbohydrate and lipid. Aquaculture, 104, $341-356$

Ackefors H., Gydemo R. and Keyser P., 1995. Growth and moulting in confined juvenile noble crayfish Astacus astacus (L.) (Decapoda, Astacidae). Freshwater Crayfish, 10, 396-409.

Acosta C.A. and Perry S.A., 2000. Differential growth of crayfish Procambarus alleni in relation to hydrological conditions in marl prairie wetlands of Everglades National Park, USA. Aquat. Ecol., 34, 389-395.

Anastácio P.M. and Marques J.C., 1995. Population biology and production of the red swamp crayfish Procambarus clarkii (Girard) in the lower Mondego River valley, Portugal. J. Crust. Biol., 15, $156-168$.

Barki A., Karplus I., Manor R., Parnes S., Aflalo E.D. and Sagi A., 2006. Growth of red-claw crayfish (Cherax quadricarinatus) in a three-dimensional compartments system: Does a neighbour matter? Aquaculture, 252, 348-355.

Belchier M., Edsman L., Sheey M.R. and Shelton P.M.J., 1998. Estimating age and growth in long-lived temperate freshwater crayfish using lipofuscin. Freshwater Biol., 39, 439-446.

Bianchini M.L., Bono G. and Ragones S., 2001. Long-term recaptures and growth of slipper lobsters, Scyllarides latus, in the strait of Sicily (Mediterranean sea). Crustaceana, 74, 673-680.

Bohl E., 1987. Comparative studies on crayfish brooks in Bavaria (Astacus astacus L., Austropotamobius torrentium Schr.). Freshwater Crayfish, 7, 287-294.

Bohl E., 1997. An isolated population of the white-clawed crayfish (Austropotamobius pallipes) in the principality of Liechtenstein. Bull. Fr. Pêche Piscic., 347, 701-712.

Brewis J.M. and Bowler K., 1982. The growth of the freshwater crayfish Austropotamobius pallipes in Northumbria. Freshwater Biol., 12, 187-200.

Brown D.J. and Brewis J.M., 1979. A critical look at trapping as a method of sampling a population of Austropotamobius pallipes (Lereboullet) in a mark and recapture study. Freshwater Crayfish, 4, $159-164$.

Dorn N.J., Urgelles R. and Trexler J.C., 2005. Evaluating active and passive sampling methods to quantify crayfish density in a freshwater wetland. J. North Am. Benthol. Soc., 24, 346-356.

Fevolden S.E. and Hessen D.O., 1989. Morphological and genetic differences among recently founded populations of noble crayfish (Astacus astacus). Hereditas, 110, 149-158.

France R.L., 1985. Relationship of crayfish (Orconectes virilis) growth to population abundance and system productivity in small oligotrophic lake. Can. J. Fish. Aquat. Sci., 42, 1096-1102.

Füreder L. and Reynolds J.D. 2003. Is Austropotamobius pallipes a good bioindicator? Bull. Fr. Pêche Piscic., 370-371, 157-163.

Füreder L., Oberkofler B., Hanel R., Leiter J. and Thaler B., 2003. The freshwater crayfish Austropotamobius pallipes in South Tyrol: Heritage species and bioindicator. Bull. Fr. Pêche Piscic., 370-371, 79-95.

Füreder L., Edsman L., Holdich D., Kozák P., Machino Y., Pöckl M., Renai B., Reynolds J., Schulz H., Sint D., Taugbøl T. and Trouilhé M.C., 2006. Indigenous crayfish habitat and threats. In: Souty-Grosset C., Holdich D.M., Reynolds J.D. and J.D. Haffner P. (eds.), Atlas of crayfish in Europe, Patrimoines naturels, Muséum national d'Histoire naturelle, Paris, 25-36.

Füreder L., Gherardi F. and Souty-Grosset C., 2010. Austropotamobius torrentium. In: IUCN 2010, IUCN Red List of Threatened Species, Version 2010.3, www.iucnredlist.org, Downloaded on 08 September 2010.

Gherardi F., Villanelli F. and Dardi P., 1996. Behavioral ecology of the white-clawed crayfish, Austropotamobius pallipes, in a Tuscan stream: preliminary results. Freshwater Crayfish, 11, $182-194$. 
Grandjean F., Romain D., Avila-Zarza C., Bramard M., Souty-Grosset C. and Mocquard J.P., 1997. Morphometry, sexual dimorphism and size at maturity of the white-clawed crayfish Austropotamobius pallipes pallipes (Lereboullet) from a wild French population at Deux-Sèvres (Decapoda, Astacidae). Crustaceana, 70, 31-44.

Grandjean F., Cornuault B., Archambault S., Bramard M. and Otrebsky G., 2000. Life history and population biology of the white-clawed crayfish, Austropotamobius pallipes pallipes, in a brook from the Poitou-Charentes region (France). Bull. Fr. Pêche Piscic., 356, 55-70.

Guan R.Z., 1997. An improved method for marking crayfish. Crustaceana, 70, 641-652.

Guan R.Z. and Wiles P.R., 1999. Growth and reproduction of the introduced crayfish Pacifastacus leniusculus in a British loweland river. Fish. Res., 42, 245-259.

Hammond K.S., Hollows J.W., Townsend C.R. and Lokman P.M., 2006. Effects of temperature and water calcium concentration on growth, survival and moulting of freshwater crayfish, Paranephrops zealandicus. Aquaculture, 251, 271-279.

Hamr P., 1996. A Giant's Tale: the life history of Astacopsis gouldi (Decapoda; Parastacidae) a freshwater crayfish from Tasmania. Freshwater Crayfish, 11, 13-34.

Holdich D.M., Haffner P. and Noël P.Y., 2006. Species files. In: Souty-Grosset C., Holdich D.M., Noël P.Y., Reynolds J.D. and Haffner P. (eds.), Atlas of Crayfish in Europe, Patrimoines naturels, Muséum national d'Histoire naturelle, Paris, 49-131.

Holdich D.M., Reynolds J.D., Souty-Grosset C. and Sibley P.J., 2009. A review of the ever increasing threat to European crayfish from non-indigenous crayfish species. Knowl. Managt. Aquatic. Ecosyst., 394-395, 11.

Huber M.G.J. and Schubart C.D., 2005. Distribution and reproductive biology of Austropotamobius torrentium in Bavaria and documentation of a contact zone with the alien crayfish Pacifastacus leniusculus. Bull. Fr. Pêche Piscic., 376-377, 759-776.

Huner J.V. and Romaire R.P., 1978. Size at maturity as means of comparing populations of Procambarus clarkii (Girard) (Crustacea, Decapoda) from different habitats. Freshwater Crayfish, 4, 53-64.

Johnson E.G., 2004. Population dynamics and stock assessment of the blue crab in North Carolina. Ph.D. thesis, Faculty of North Carolina State University, 234 p.

Jones J.B., 1981. Growth of two species of freshwater crayfish (Paranephrops spp.) in New Zealand. New Zeal. J. Mar. Fresh. Res., 15, 15-20.

Jones J.P.G. and Coulson T., 2006. Population regulation and demography in a harvested freshwater crayfish from Madagascar. Oikos, 112, 602-611.

Kappus B., Peissner T. and Rawer-Jost C., 1999. Distribution and habitat conditions of crayfish populations in the urban freshwater systems of Stuttgart (Baden-Württemberg, Germany). Freshwater Crayfish, 12, 778-785.

Laurent P.J., 1988. Austropotamobius pallipes and A. torrentium, with observations on their interactions with other species in Europe. In: Holdich D.M. and Lowery R.S. (eds.), Freshwater Crayfish: Biology, Management and Exploitation, Croom Helm, London, 341-364.

Lewis S.D. and Horton H.F., 1996. Life history and population dynamics of the signal crayfish, Pacifastacus leniusculus, in Lake Billy Chinook, Oregon. Freshwater Crayfish, 11, 34-53.

Lindquist O.V. and Lahti E., 1983. On the sexual dimorphism and condition index in the crayfish, Astacus astacus L. in Finland. Freshwater Crayfish, 5, 3-11.

Lowery R.S., 1988. Growth, moulting and reproduction. In: Holdich D.M. and Lowery R.S. (eds.), Freshwater Crayfish: Biology, Management and Exploitation, Croom Helm, London, 83-113.

Maguire I. and Gottstein-Matočec S., 2004. The distribution pattern of freshwater crayfish in Croatia. Crustaceana, 77, 25-49.

Maguire I., Erben R., Klobučar G.I.V. and Lajtner J., 2002. Year cycle of Austropotamobius torrentium (Schrank) in streams on Medvednica mountain (Croatia). Bull. Fr. Pêche Piscic., 367, 943-959.

Maguire I., Klobucar G., Faller M., Machino Y., Kucinic M. and Zuzul M., 2006. Updates on the distribution of the white-clawed and the narrow-clawed crayfish in Croatia. Crayfish News, 28, 4-5.

Narodne novine, 1999. Proglašavanje divljih svojti zaštićenim i strogo zaštićenim.

Narodne novine, 2008. Zakon o izmjenama i dopunama Zakona o zaštiti prirode.

Nowicki P., Tirelli T., Sartor R.M., Bona F. and Pessani D., 2008. Monitoring crayfish using mark-recapture method: potentials, recommendation, and limitations. Biodivers. Conserv., 17, 3513-3530. 
Nyström P. and Granéli W., 1996. The effect of food availability on survival, growth, activity and the number of mature females in crayfish populations. Freshwater Crayfish, 11, 170-181.

Parkyn S.M., Collier K.J. and Hicks B.J., 2002. Growth and population dynamics of crayfish Paranephrops planifrons in streams within native forest and pastoral land uses. New Zeal. J. Mar. Fresh. Res., 36, 847-861.

Peay S., 2009. Invasive non-indigenous crayfish species in Europe: Recommendations on managing them. Knowl. Managt. Aquatic. Ecosyst., 394-395, 03.

Rabeni C.F., Collier K.J., Parkyn K.J. and Hicks B.J., 1997. Evaluating methods of sampling stream crayfish. New Zeal. J. Mar. Fresh. Res., 31, 693-700.

Renz M. and Breithaupt T., 2000. Habitat use of the crayfish Austropotamobius torrentium in small brooks and in Lake Constance, Southern Germany. Bull. Fr. Pêche Piscic., 356, 139-154.

Scalici M., Belluscio A. and Gibertini G., 2008. Understanding population structure and dynamics in threatened crayfish. J. Zool., 275, 160-171.

Skurdal J. and Taugbøl T., 1994. Do we need harvest regulations for European crayfish? Rev. Fish Biol. Fish., 4, 461-485.

Söderbäck B., 1995. Replacement of the native crayfish Astacus astacus by the introduced species Pacifastacus leniusculus in a Swedish lake: possible causes and mechanisms. Freshwater Biol., 33, 291-304.

Souty-Grosset C. and Reynolds J.D., 2009. Current ideas on methodological approach in European crayfish conservation and restocking procedures. Knowl. Managt. Aquatic. Ecosyst., 394-395, 01.

Streissl F. and Hödl W., 2002. Growth, morphometrics, size at maturity, sexual dimorphism and condition index of Austropotamobius torrentium Schrank. Hydrobiologia, 477, 201-208.

Thorsteinsson V., 2002. Tagging methods for stock assessment and research in fisheries. In: Arnold G., Davenport J., Ó Maoiléidigh N. and Thorsteinsson V. (eds.), Report of Concerted Action FAIR CT.96.1394 (CATAG), Reykjavík, 21-22.

Troschel H.J., Schulz U. and Berg R., 1995. Seasonal activity of stone crayfish Austropotamobius torrentium. Freshwater Crayfish, 10, 196-200.

Ulmestrand M. and Eggert H., 2001. Growth of Norway lobster, Nephrops norvegicus (Linnaeus 1758), in the Skagerrak, estimated from tagging experiments and length frequency data. J. Mar. Sci., 58, $1326-1334$.

Vorburger C. and Ribi G., 1999. Pacifastacus leniusculus and Austropotamobius torrentium prefer different substrates. Freshwater Crayfish, 10, 696-704. 